\title{
ENHANCING THE LEARNING OF PACKAGING DESIGN THROUGH SERVICE-LEARNING PROGRAMS
}

\author{
Listia Natadjaja and Elisabeth Christine Yuwono
}

\section{Abstract}

Learning packaging design requires knowledge of the design theory and practice of packaging making that can then be applied in the community. Our packaging design class was first implemented as a regular program for five years and has been a service-learning (S-L) program for 13 years. We observed that the quality of packaging design learning improved after implementing the $S$-L program. In order to identify an effective program, we examined packaging design learning by comparing classes that use a regular program to classes that implement the S-L program. We collected the data from students' reflections and interviews with them. The study outcomes provide important discussions about S-L programs and how students enbance their learning by moving from passive through active learning to solve real design problems. Through the experiences of dealing with real clients and problems, students develop their sense of civic responsibility and citizenship. Moreover, students have contributed their packaging design to the welfare of urban and rural people in need. Regarding character development, students become more concerned with their attitudes. In addition to the positive outcomes from a S-L program, we also evaluate some challenges related to economic, cultural, and social aspects of S-L. The S-L program helps us to solve real problems in packaging design.

\section{Introduction}

The Visual Communication Design Department at Petra Christian University has held packaging design classes as an elective since 2000. In 2000-2005, we implemented a traditional program. During that time, our class objectives were to introduce packaging design and the kinds of elements needed in designing packaging so students could implement effective plans using modern equipment. The class curriculum offered beginning knowledge about packaging and development as well as about the impact of packaging design on marketing and other factors supporting the packaging design process (Jurusan Deskomvis, 2006). At that time, students 
learned about packaging design and made their packaging design as creative as possible for the main purpose of getting grades and exhibiting their work. Students struggled to make their packaging design effort connect as closely as possible with the examples and theory taught in class. We regretted to see that the wonderful work of students was only for display but could not be used for society.

Then, in 2006, our packaging design class tried to implement service-learning (S-L) for the first time. We recognized that $\mathrm{S}$-L is a teaching and learning approach that integrates community service with academic studies. S-L can enrich students' learning, teach them civic responsibility, and also strengthen communities. It engages students in addressing real unmet needs or issues in a community and actively involves them in decision-making at all levels of the process (National Commission on Service Learning, 2002). We believed that by implementing S-L, students could contribute their knowledge to the community and enhance the quality of their study of packaging design. As Campbell said, S-L is a type of experiential learning that engages students in service within the community as an integrated aspect of a course. Students participate in an organized service activity and reflect on that activity in such a way as to gain further understanding of course content, a broader appreciation of the discipline, and an enhanced sense of personal values and civic responsibility. Service-Learning engages students in active, collaborative, and inquiry-based learning experiences that meets identified community needs (Campbell, 1998).

According to Campbell, through a S-L program, students can have opportunities to engage with the community in active learning, which often leads to greater involvement and a more fulfilling educational experience. Higher education students need to disseminate and apply their knowledge (Rao, 2003).

After a few years of implementing a S-L program in packaging design, we found some different conditions between the regular program class and the S-L program. In the S-L model, we discovered that the connection between theoretical and practical that occurs when students are involved with the community could not be found in the regular program. As Buchanan said regarding the design field, a designer needs to experience a problem in real situation. It is time for school to deal with design requirements as professionals do. It is an immediate problem to integrate design into industry to answer the cultural question about the role of design in modern world and how it can contribute to human experience (Buchanan, 1995, p. 82).

We found some advantages in the S-L program that benefited our students. We noticed that our students participated well in the S-L program, and the outcomes enhanced their learning ability in technical and soft skills. This article tries to examine how the S-L program enhanced the learning of packaging design, especially by analyzing the class that took part in the S-L program. Hopefully we can clearly see the advantages and the obstacles and share the strategies in integrating the advantages of both methods to make better S-L programs.

\section{Methods}

This research primarily used qualitative methods. The data from the regular class was based on our observations in classes and supported by interviews with tutors. Meanwhile, the data from the S-L program was based 
on the students' reflections. An important part of S-L is the making of reflection reports. Reflection involves students writing down their thoughts, feelings, and ideas (Winings, 2002, p. 114). Reflection helps students to: (a) evaluate the program constructively, (b) evaluate their own contributions to the project, (c) assess factors that may have created the problem, and $(\mathrm{d})$ evaluate appropriate responses and resolutions to the problem (Winings, 2002, p. 111). In this research, reflection reports were the primary resource that helped us to evaluate students' experiences in the S-L program in order to enhance the quality of future programs. The reflection process was a critical part of the S-L experience, because student reflections bridged the community service activities and the educational content of the course in a way that produced new learning that could not be found in the course content (Bringle \& Hatcher, 2010, p. 5).

Reflection is an essential way for students to bridge doing and understanding (Dubinsky, 2006, p. 307). In total, there were 377 reflection reports from 2006-2018. We have selected the best reflection reports based on project evaluations, narrative ability, field of knowledge, and honesty. We classified the selected quotes based on the theory of Waterman (1997) that categorizes the outcomes of a good S-L program. Parts of students' reflections are quoted to clarify analysis. As Bringle and Hatcher (2010) posit, quotes are one of the strategies to represent student's experience with service-learning. It also describes thoughts about the service experience (Gateway Technical College, 2013, p. 14). Quotes give an expressive model, which could result in more authentic, varied responses that address areas of student concern (Sturgill \& Motley, 2014, p. 85).

\section{Mechanism of Regular and S-L Program in Packaging Design Class}

In 2000, when the packaging design class started for the first time, the course consisted of 60 students. During the semester, students only studied in class and did some small tasks individually. Then we thought about developing a project, creating a studio, and hiring tutors to assist some students with their projects. So in the next two years, we offered packaging design knowledge in theory and also practice. Lecturers taught in class, and four tutors assisted students with their projects in the studio. We also limited the number of students; the average number of students in class was between 24 to 40 students, so each tutor assisted 6 to 10 students. Sometimes students worked individually, but most of the time they met in groups. Students learned about packaging design theory, completed a big project in the middle of the semester, and had an evaluation at the end of semester. In accordance with the current curriculum that focuses on marketing, students were required make their packaging design as unique and creative as possible. In total, our students made about 300 packaging designs in five years. 

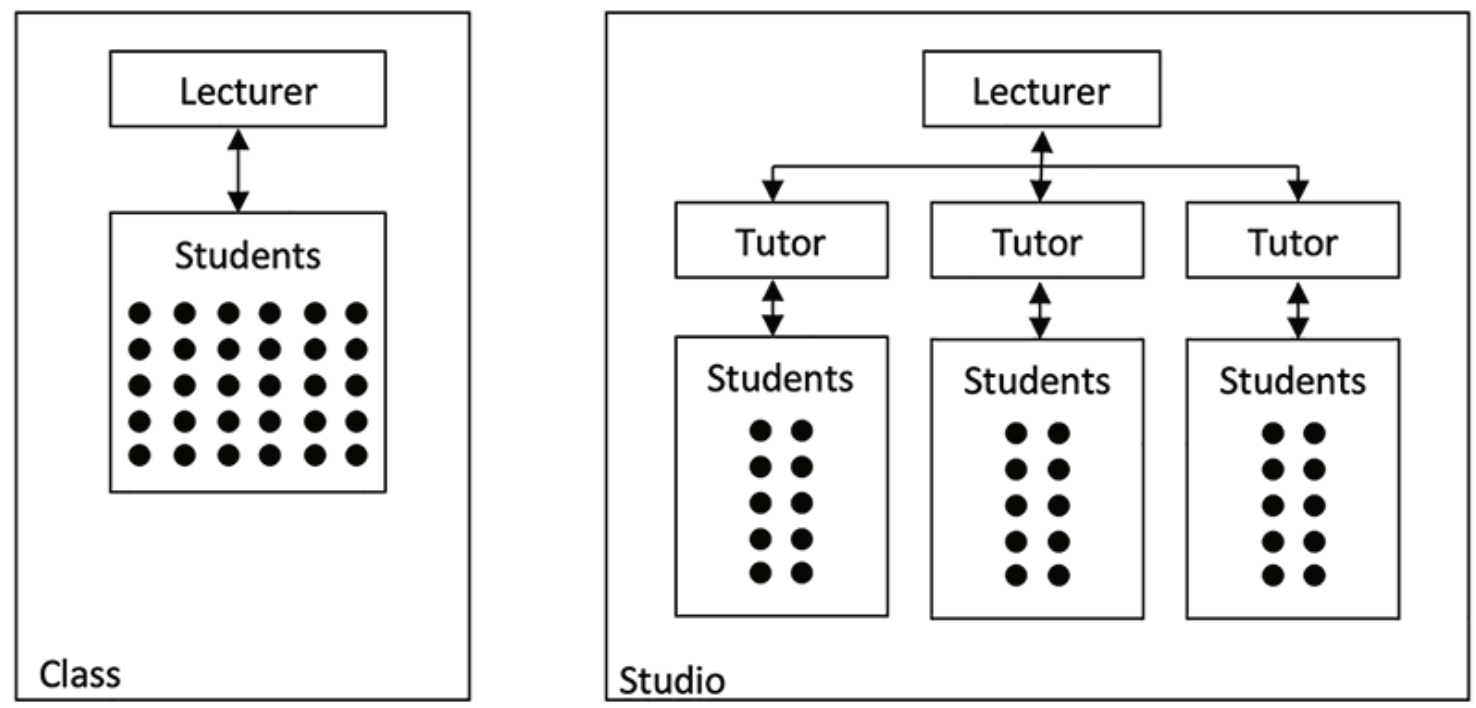

Figure 1. Class and studio learning.

In 2006, when we began to implement the S-L program, we still adopted class and studio learning and limited the number of students to approximately the same as the previous, regular program. Students, in groups or individually, met a micro industry and helped them to solve the problem related to their packaging design. At first, the S-L program focused on helping micro industries in urban areas like Surabaya and Sidoarjo. Students had to find a micro industry that needed help in designing their packaging. All groups of students created the design, and in addition, some groups also did product registration for the micro industries. In total, there were 30 students, and they produced seven packets of packaging designs. From 2007 to 2009, facilitated by the Community Outreach Centre, the packaging design class of the Visual Communication Design major at Petra Christian University implemented S-L to assist micro industries organized by the Family Empowerment and Welfare Executive Committee in Kediri district (PKK Kabupaten Kediri) (Natadjaja \& Cahyono, 2009). In 2007, there were 30 students that produced 15 packaging designs. In 2008, there were 34 students and 34 packaging designs; in 2009, there were 31 students and 31 packaging designs. In total, 80 packaging designs were made for the micro industries in Kediri for the duration of three years.

In 2010, we helped four micro industries in Rungkut, a sub-district of Surabaya. There were 32 students involved and four packets of packaging design produced. In 2011, 31 students helped micro industries in Surabaya and produced 15 packaging designs. In 2012, there were 24 students and 24 packaging designs for micro industries. In 2013, there were 34 students who tried to help six micro industries from Madiun. From 2006 until 2013, we mostly designed packaging for snacks or beverages, but in 2014, we selected clients that produce products that cannot be consumed. In 2014, there were 40 students that helped 20 micro industries from Surabaya, our hometown. In 2015, with 34 students, they contributed 17 packaging designs. In 2016, facilitated by the Community Outreach Program, we cooperated with the Mojokerto district to help their Family Empowerment and Welfare Executive Committee to produce 15 packagings that were designed by 30 students. In 2017, the number of packaging classes was decreased because of the offering of new elective classes; 
with 10 students in 2017 and 17 students in 2018, we helped micro industries that supported multinational companies and produced 10 and 17 packagings. So, in total, from 2006-2018, we have collected 377 reflection reports from 377 packaging design students and have produced 215 packaging designs that have contributed to urban and rural communities.

Table 1.

The Number of Students, Reflection Reports, and Packaging Designs in S-L Program, 2006-2018

\begin{tabular}{|l|l|l|l|l|}
\hline No. & Year & $\begin{array}{l}\text { Number } \\
\text { of } \\
\text { students }\end{array}$ & $\begin{array}{l}\text { Reflection } \\
\text { reports }\end{array}$ & $\begin{array}{l}\text { Packaging } \\
\text { Designs }\end{array}$ \\
\hline 1. & 2006 & 30 & 30 & 7 \\
\hline 2. & 2007 & 30 & 30 & 15 \\
\hline 3. & 2008 & 34 & 34 & 34 \\
\hline 4. & 2009 & 31 & 31 & 31 \\
\hline 5. & 2010 & 32 & 32 & 4 \\
\hline 6. & 2011 & 31 & 31 & 15 \\
\hline 7. & 2012 & 24 & 24 & 24 \\
\hline 8. & 2013 & 34 & 34 & 6 \\
\hline 9. & 2014 & 40 & 40 & 20 \\
\hline 10. & 2015 & 34 & 34 & 17 \\
\hline 11. & 2016 & 30 & 30 & 15 \\
\hline 12. & 2017 & 10 & 10 & 10 \\
\hline 13. & 2018 & 17 & 17 & 17 \\
\hline & Total & 377 & 377 & 215 \\
\hline
\end{tabular}

We have adopted class and studio learning both in the regular program and in our S-L program. Studio learning is effective for students to get some useful information about their design from their tutor. In the S-L program, the role of the lecturer and tutor are not only as educators but also as facilitators between students and their clients. We have the same learning process between the regular and the S-L program, which includes class learning, studio learning, design process, and at the end of the semester, students must have an exhibition. In the S-L class, students also have a field experience. They must interact with the printing industry in order to implement their design. Students must package their clients' products in new packagings, hold an exhibition, 
and sell the products. In addition to students receiving a grade, the exhibition and sales are done in appreciation to the micro industry (Natadjaja \& Cahyono, 2009).

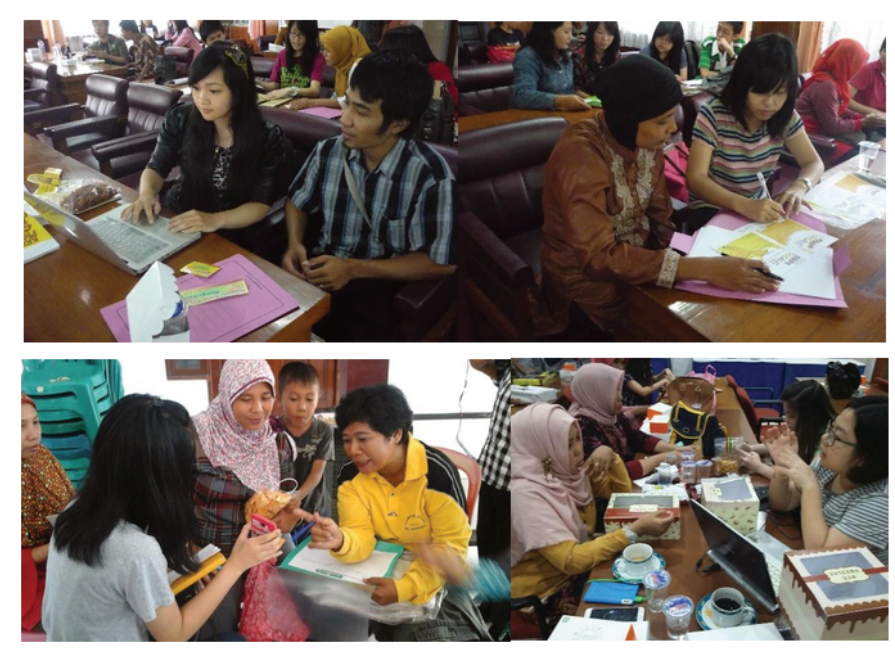

Figure 2. The consultation process and presentation of new packaging design.

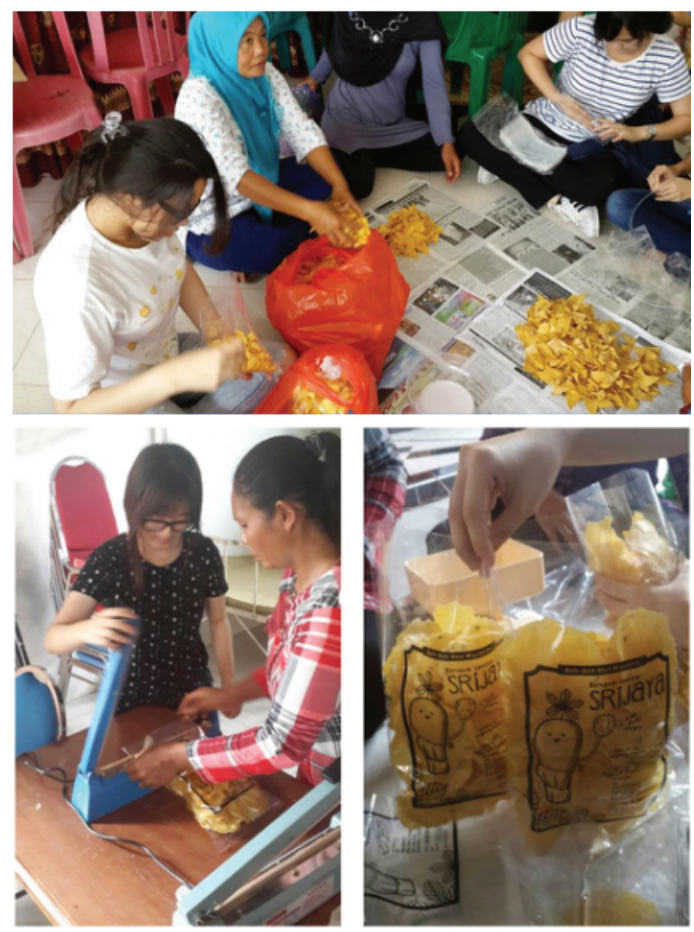

Figure 3. The process of packaging the product. 


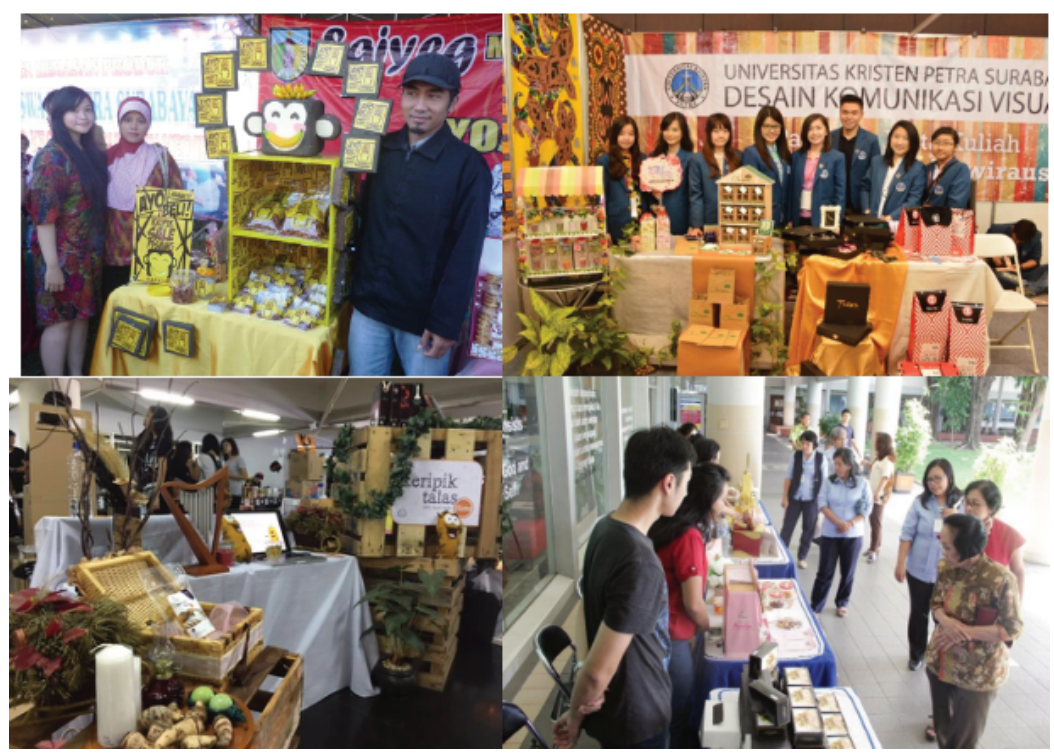

Figure 4. Exhibition and selling.

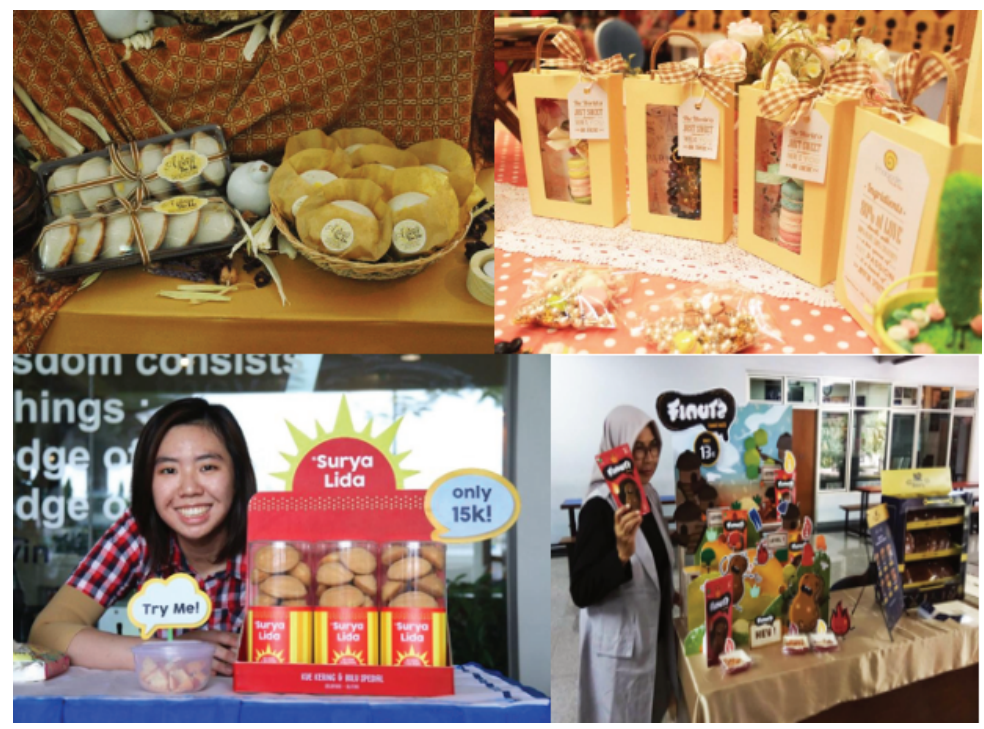

Figure 5. Packaging design by students (from above: Sinta Gunawan, Steven Gunawan, Mariske Budiman, and Ivana Wayadi). 
Table 2.

Learning Process in Regular and S-L Program

\begin{tabular}{|l|l|l|l|l|}
\hline \multirow{2}{*}{ No. } & \multicolumn{2}{|c|}{ REGULAR PROGRAM } & \multicolumn{2}{c|}{ S-L PROGRAM } \\
\cline { 2 - 5 } & Learning Process & Interaction & Learning Process & Interaction \\
\hline 1. & Class learning & Student-lecturer & Class learning & Student-lecturer \\
\hline 2. & Studio learning & Student-tutor & Studio learning & Student-tutor \\
\hline 3. & Design process & Student-tutor & Design process & Student \\
\hline 4. & - & - & Field experience & Student-client-tutor \\
\hline 5. & - & - & Design implementation & $\begin{array}{l}\text { Student-industry } \\
\text { (printing) }\end{array}$ \\
\hline 6. & Exhibition & Student-tutor & $\begin{array}{l}\text { Exhibition \& product } \\
\text { selling }\end{array}$ & Student-client-tutor \\
\hline
\end{tabular}

\section{The Outcomes of a S-L Program}

Reflection is a conscious review of the day's or week's events and activities with the purpose of finding meaning. It is the opportunity to look back on our actions and experiences so as to help us "shape our future, actions, goals, and beliefs" (Goldsmith, 1995, p. 1). It is through reflection that the students will actually see what they are learning (Eyler, Giles, \& Schmiede, 1996). In this research, we analyzed some reflections only from the packaging class that implemented the S-L program because students did not make reflections in the regular program. Reflection reports are very helpful to get a description about what the students think, feel, and do while they did the project. According to Waterman, most developers categorize the outcomes of a good S-L programs in four areas: (a) enhancing learning through active learning, (b) promoting of character development, (c) nurturing a sense of civic responsibility and citizenship, and (d) making a contribution to the community.

\section{Enhancing Active Learning}

In the traditional approach, or as referred to in this article, the regular program, students spent most of the time listening and watching the lecturer in the classroom. The students worked individually on assignments, and cooperation was limited (Bonwell \& Eison, 1991). Analysis of the research literature suggests that students must be actively involved. They must do more than just listen to the lecturer in the classroom. Students should be able to do activities like read, write, discuss in order to solve the problem. Moreover, students must engage in many tasks that require higher-order thinking such as analysis, synthesis, and evaluation (Chickering and Gamson, 1987). However, active learning also emphasizes exploration of students' values and attitudes (Brame, 2016). In their seminal work Active Learning: Creating Excitement in the Classroom, Bonwell and Eison (1991) 
defined active learning as "instructional activities involving students in doing things and thinking about what they are doing" (p. iii).

The research outcomes indicate that $\mathrm{S}$ - $\mathrm{L}$ can enhance the quality of the learning of packaging design. In the class, students received theoretical knowledge, and with that theory they were able to make a good design. In the regular program, a good design could be made only with a computer and printer; students just needed to print their design. But in the S-L program, in order for the design to be used by the clients, students had to print their designs in larger quantities, like in the industry, with screen printing or offset printing. Because of this condition, students had to learn about choosing materials, printing techniques and processes, managing time and budget. Students also had to compare the theory that they learn in class and implementation in the field. They were fascinated with the images of modern packaging design in books and were willing to make their designs look like them. Students who had clients with less financial means felt jealous toward students who had clients with greater means. Instead of focusing on their own design and thinking about making packaging with minimal budgets, they blamed a low budget for not being able to create a good design.

Budgeting was one of the main challenges in this project and was one of the factors that distinguished between the regular and S-L programs. Students did not have experience with a real budget, so they had to be very careful not to make their clients suffer a financial loss because of their expensive packaging design. Students did not want to make the least expensive design, because they did not want their design to look cheap. Here students learned by themselves how to calculate packaging budget that is suitable for their clients.

I'm not only concerned about the design but also the needs of clients, I have to be able to calculate the cost which will be spent on packaging according to the product sales and adjusted to the profit of the product so that the packaging is not too expensive or too cheap. I have to know what kind of design is desired and needed by the market and the characteristics of the product to be designed. In addition, I gain knowledge about how to print (prepress, press and post-press), kinds of materials used, printing techniques, printing processes, and finishing techniques, such as cutting, folding, and packing. (Chrysantia US-42407007)

In addition, besides gaining knowledge about packaging design, it turns out that many students learned about the products that are packaged. Usually their micro industry clients gave some information about the characteristics of their products, how they manage to get the raw materials, how to process and sell them. A major component of S-L is the constant exchange that takes place between the student performing the service and the individual or agency receiving the service. It is this notion of reciprocity that distinguishes S-L from other forms of experiential learning. The nature of this exchange is one of mutual respect, learning, and development (Winings, 2002, p. 11). It turns out that through the interaction and relation with the community, students not only contributed to the community but also gained knowledge that they could not obtain in the classroom.

The jackfruit chips are produced seasonally only, and producers do not have any supply after the jackfruit season ends. Consumers will be disappointed if they want to buy jackfruit chips, but the product is not produced, especially when the existing name and labeling (brand) are known and sought-after by people. (Devi Dianita Ganiarsa-42405006) 
We also got a bit of knowledge from Mangrove plants. It turns out that it can be cultivated and produced to various kinds of products to be sold. (Marsellina-42407159)

The spirit of active learning is aimed at gaining knowledge as well as sharing knowledge. Even though the students do the assignments individually, discussion is done in groups. For students, learning new things and meeting new people was a challenge that had positive impact.

I learned from friends that everything done alone is unpleasant, working on things together is very useful. I learned new things that I've never known before and met people that I never get to meet before in my social environment. (Mariske-42414065)

\section{Strengthen the Character Development through the Gaps}

Modern education is mostly focused on students' academic and physical development. In the modern era, educators begin to recognize the need for new but still traditional approaches to education that not only emphasize intellectual development but also strengthen character development. Character education is an approach to education that integrates values, ethics, emotional maturity, and a sense of civics. A comprehensive definition of character includes thoughts, emotions, and actions (Spallino, 2017).

In spite of all the good things that happened in the S-L program, we saw different social backgrounds create some gaps between the students and clients. We found that there are some obstacles faced by students related to economic, cultural, and social gaps.

Most of the students think that a good design must be expensive, so integrating it to the need of a small budget is difficult. Financial aspects became a sensitive topic; most of the students avoided asking clients about their financial condition much less to fund part of their projects. Sometimes, students believed that their clients were economically deprived, so they made the design as cheap as possible. However, some students encouraged themselves to ask for financial support from their clients, even though only a few of them succeeded. The way they communicated and their attitude determined the success or failure of negotiations with clients.

Integrating the need and the financial factor is extremely difficult, because of the opposite character of them. But this is a new knowledge that must be learned by the designer. In S-L, the designer must know the preferences of the wider public, and also the interest of the market. (Devi Dianita Ganiarsa-42405006)

An important result of S-L is that the students have experience dealing with real clients and real problems. They must not follow their ego but understand their clients' needs. The control of the ego is related to not only the design process but also the students' relations to friends in their team and clients. This packaging design project must be done until it can be used by the client. Students must really consider their clients' requests. Here, students also learn to have empathy and self-control.

Through S-L, I was "challenged" not only to struggle with my "ego" in my design, but also was demanded to see reality, both in terms of sale prices, characteristics, and consumer products. (Grace Giovani S-42407060) 
Social interactions in this S-L program had a positive impact on the formation of student character. They learned to behave, to persuade, and to control their emotions.

I learn how to advise clients but do not offend clients' opinions. I learn to persuade clients to agree with me and I learn to be patient when she asks me to revise my design repeatedly. (Ivana H. Wijaya-42415125)

Here we see that the real client and real project can become a positive boundary in the way that the students should position themselves in the client's point of view. As Winings said, “As young people develop, learning about boundaries, societal rules and self-discipline are important concepts to acquire. This is often a challenging and difficult lesson for young people to master. With their tremendous energy, dynamism and creativity, learning to control those impulses and to become responsible young men and women was not easy. But we knew that it is necessary” (p. 39).

\section{Civic Responsibility and Citizenship}

The term "civic responsibility" means not only to live in a democracy but also to practice the ideas of citizenship: social responsibility, civic engagement, and community involvement. Active participation in the public life of a community in an informed, committed, and constructive manner, with a focus on the common good, can be civic responsibility (Gottlieb \& Robinson, 2006). Pluralism enriches students' education, helps them to respect differences, and helps them work for the common good (Campus Compact, 1999). Some people think that civic responsibility and citizenship only relate to human rights and civic obligations, state responsibility, law enforcement, democracy, or national pluralism, but civic responsibility and citizenship have a broader meaning.

My idea of citizenship has changed as a result of service learning. Before this assignment, I believed that citizenship was only about voting and abiding by laws. We need to endorse our political efficacy ... A civil society lacking active citizens possesses no enrichment, diversity, or meaning. - Service-learning student, Miami-Dade Community College

Students not only develop their hard skills but also become more concerned with their attitudes, especially how to be polite and how to use proper language visually and verbally. Students will be challenged in terms of attitudes and habits through the service component. Compassion and empathy naturally emerge as a result of their project work (Winings, 2002, p. 19).

Many times communication became the main problem in this project. There was a language barrier between students and micro industries. Mostly our students speak Bahasa Indonesian in their daily lives, but their clients speak Javanese, and few of them speak Maduranese. During interactions with the manufacturers, there were difficulties in terms of communication and also the frequent occurrence of miscommunication between students and producers. Usually students solve the problem by using formal and polite language in Bahasa Indonesia in order to avoid their client becoming offended or have misunderstandings. Even though students 
faced difficulties, some of them could see the obstacles in a positive light. They became appreciative of cultural diversity, through the difference of religions, languages, ethnicities, education, social and economic backgrounds, etc.

With this Service-Learning method, I learn how to deliver materials and messages to others (micro industry) by using the language that can be grasped and understood by them. Our clients come from ethnic Madura, so we had to use a language that is really formal. In designing the packaging, we need to have intensive communication and interaction with the clients. (Sinta Gunawan-42408044)

There were different educational backgrounds between students and clients. Because of that, students experienced that it was easier for them to relate to their tutor than to their client. In a positive way, students saw the social gaps as a challenge to understand their clients and to have a strategy to convince them.

Presenting the concept of design that I created in front of the small entrepreneur is very different from presenting it to the tutor. It must have been because of their different backgrounds with our tutor. Different backgrounds would require different approaches. How to choose your words that must be used in order to convey the design concepts that make it easily understood. (Yose Yoewono-42407093)

By impacting a student's scope of the country, the S-L program can trigger civic responsibility on a larger scale, including a desire to be involved in social activities through the city government.

In the future if there is an opportunity, I can cooperate with the TATARUPA movement, a Service-Learning activity that improves Surabaya's economy run by Kreavi and Surabaya Economic Heroes. (Mariske-42414065; Joanna Widjaja-42414027)

\section{The Contribution of Packaging Design to the Community}

The students' designs were not just graded and exhibited, but their designs were donated and implemented. Through S-L, some students have contributed to the welfare of urban and rural people in need. Some students felt very happy and satisfied to see their design was appreciated and used by their client. In the S-L program, students not only contributed their ideas and knowledge in the form of design but also involved their "hearts" for their clients. They felt happy when their clients recognized their design and vice versa. They felt inner satisfaction with the result.

When I can manage to make packaging design, and gave it to Mrs. Erlin, I feel very happy. That's because my packaging design can help Nata Cake business that is not widely known. I feel happy to work together in helping the community, especially the micro industry. There is also a sense of satisfaction because the client will make real packaging in mass production. Mrs. Erlin is quite satisfied with the results of the packaging and Point of Purchase (POP) which is displayed. (Lenny Andriani-42408024) 


\section{Solving Real Design Problems in Packaging Design}

Based on those data, we tried to analyze both the regular class and the S-L program. Students in the regular program were mostly focused on the design process. The class emphasis was usually on skill level, like how to make a unique, creative, elegant, or modern packaging design. The class projects resulted in students intent on making expensive and complicated packaging design structures. Students referred to the books of packaging design for the making of ideas and design concepts. Students did not have to take budget into account, so their designs were sometimes unrealistic to implement because they cost too much. Students also did not have field experience; they did the designs at home and only asked opinions of their tutor. Students in the regular program only needed to make a few models of their designs, so they did not need to go to the industry to have screen printing or offset printing. Because of that, students had less technical knowledge. At the end of the semester, they had to exhibit their products, and after their tutor gave marks, they could then bring their designs home. The number of packaging designs in the exhibit increased each year because of the competition among students.

We saw that this kind of learning only focused on acquiring a good grade and compliments on the students' designs. At the end, their designs could not be implemented because of their complex packaging structures technically and they were unrealistic financially. Finally, the students only made fictitious designs for their portfolio (Wijayanti, Maer, \& Fabrianne, 2017). Because students in the regular program did not have real clients, they did not have field experience, they did not have interactions with other people with different backgrounds, therefore the packaging design class only focused on solving design problems. Once their designs were graded, they finished their jobs. They did not have other responsibilities regarding the implementation of their designs. The works of students were not usable, even though there were many people who needed their packaging designs.

Real clients and real problems in S-L have a huge impact on the students' learning process. In the design process, the existence of the real clients gave some boundaries related to time management and budget. "The other part of this lesson is learning to keep one's word, becoming a person of integrity and someone who can be trusted" (Winings, 2002, p. 39). Students had to keep their promise to their clients. Students made creative designs with realistic budgets. Students implemented their design, so they had to learn many things related to technical matters, like prepress, press, and post-press. In class, students could still get some advice from their tutor. However, the way that they communicated with their clients was totally different. Language became a barrier. Petra's students come from many other places in Indonesia and are not only from the Java island, so some students found it difficult to know what their clients said, moreover understand their clients' needs. Even though our students are born in Java, most cannot speak Javanese, especially fine Javanese language. In this situation, both students and their clients had to speak properly using the formal language Bahasa Indonesia.

Students also faced significant economic, cultural, and social gaps because they have different backgrounds. Eventually, this situation affected the students' attitudes; they do not want their clients to get offended, so they had to use proper language, dress politely, and make themselves well prepared. This condition made the stu- 
dents have self-control. On one hand, students fulfilled their clients' needs, but on the other hand, students had to apply their design knowledge and understand their client. The gaps between students and clients became the means of learning through which to strengthen students' character development. In the S-L program, students contributed their packaging design to the community, so they designed with empathy because they were solving real problems, not only design problems.

The regular program mostly focused on the design, whereas the S-L program had broader concern in both design as well as human understanding. It emphasized hard skills as well as soft skills. Not only were students concerned about design, but they also had to be concerned with design skills, technical knowledge, and management skills. At the soft skill level, communication skills were needed so that there was no misunderstanding among students, their clients, and tutors. Moreover, when they were dealing with clients, they paid attention to their attitude and applied their empathetic perspective to the project. Working in different environments also made them respect differences and be more responsible. We believe that designing with a "heart" created a different impact for both the students and clients. 
Table 3.

Outcomes in Regular and S-L Program

\begin{tabular}{|c|c|c|c|c|}
\hline Outcomes in S-I & & Regular class & S-L class & $\begin{array}{l}\text { Values from S-L } \\
\text { class }\end{array}$ \\
\hline \multirow[t]{8}{*}{ Active learning } & Design & $\begin{array}{l}\text { Unique, creative, } \\
\text { elegant \& modern }\end{array}$ & Unique, creative \& modern & \multirow{8}{*}{$\begin{array}{l}\text { Creativity in } \\
\text { designing } \\
\text { packaging within } \\
\text { realistic conditions }\end{array}$} \\
\hline & & $\begin{array}{l}\text { Expensive \& } \\
\text { complicated }\end{array}$ & Simple & \\
\hline & & $\begin{array}{l}\text { Unrealistic design } \\
\text { \& budget }\end{array}$ & Implemented design & \\
\hline & & Class experience & Class \& field experience & \\
\hline & & $\begin{array}{l}\text { Graded \& } \\
\text { exhibited }\end{array}$ & $\begin{array}{l}\text { Graded, exhibited } \\
\text { donated \& implemented }\end{array}$ & \\
\hline & Technical & $\begin{array}{l}\text { Less technical } \\
\text { knowledge }\end{array}$ & $\begin{array}{l}\text { More technical knowledge } \\
\text { (prepress, press, and post- } \\
\text { press) }\end{array}$ & \\
\hline & Management & $\begin{array}{l}\text { More dependent } \\
\text { on class schedule }\end{array}$ & $\begin{array}{l}\text { More independent in } \\
\text { managing time }\end{array}$ & \\
\hline & & $\begin{array}{l}\text { No financial } \\
\text { management }\end{array}$ & Need financial management & \\
\hline \multirow[t]{3}{*}{$\begin{array}{l}\text { Character } \\
\text { development }\end{array}$} & Communication & $\begin{array}{l}\text { Two-way } \\
\text { communication } \\
\text { (students to } \\
\text { lecturer and or } \\
\text { tutor) }\end{array}$ & $\begin{array}{l}\text { Multiple ways of } \\
\text { communication (student to } \\
\text { lecturer, tutor, client [micro } \\
\text { industries], industry [screen } \\
\text { printing, offset printing], } \\
\text { etc.) }\end{array}$ & \multirow[t]{3}{*}{$\begin{array}{l}\text { Maturity in } \\
\text { thought, emotion, } \\
\text { and action in } \\
\text { design process }\end{array}$} \\
\hline & Attitude & Informal & $\begin{array}{l}\text { Formal and more polite to } \\
\text { real client }\end{array}$ & \\
\hline & Empathy & $\begin{array}{l}\text { Understand tutor } \\
\text { instruction }\end{array}$ & Understand clients' need & \\
\hline \multirow[t]{3}{*}{$\begin{array}{l}\text { Civic } \\
\text { responsibility } \\
\& \text { citizenship }\end{array}$} & $\begin{array}{l}\text { Respecting } \\
\text { diversity }\end{array}$ & $\begin{array}{l}\text { No economic, } \\
\text { cultural and social } \\
\text { gap }\end{array}$ & $\begin{array}{l}\text { Economic, cultural \& social } \\
\text { gap }\end{array}$ & \multirow[t]{3}{*}{$\begin{array}{l}\text { Awareness of } \\
\text { diversity and social } \\
\text { responsibility }\end{array}$} \\
\hline & & $\begin{array}{l}\text { No language } \\
\text { barrier }\end{array}$ & $\begin{array}{l}\text { Language barrier (Javanese, } \\
\text { Maduranese \& Indonesian } \\
\text { language) }\end{array}$ & \\
\hline & Responsibility & $\begin{array}{l}\text { Responsible to } \\
\text { complete the } \\
\text { course work }\end{array}$ & Responsible to community & \\
\hline $\begin{array}{l}\text { Contribution } \\
\text { to community }\end{array}$ & Packaging design & No contribution & $\begin{array}{l}\text { Packaging design } \\
\text { contribution }\end{array}$ & Inner satisfaction \\
\hline Goal & & $\begin{array}{l}\text { Solving design } \\
\text { problems }\end{array}$ & $\begin{array}{l}\text { Solving real design } \\
\text { problems }\end{array}$ & $\begin{array}{l}\text { Reliable in hard } \\
\text { skills and soft } \\
\text { skills }\end{array}$ \\
\hline
\end{tabular}




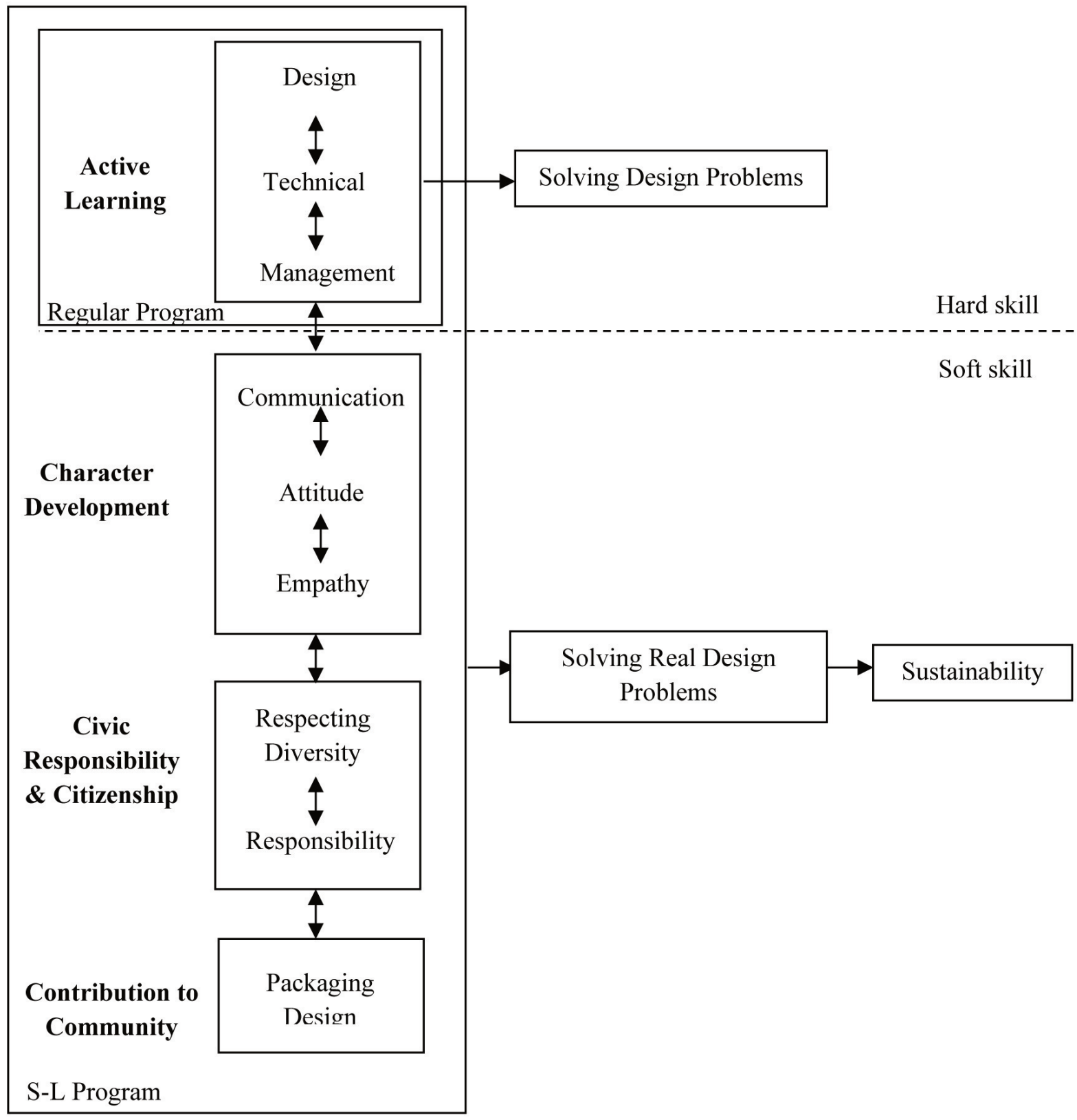

Figure 6. The goals of regular and S-L programs.

\section{Conclusions}

This study of packaging design related not only to technical skills. A regular program gave students the ability to create unique, creative, elegant, and modern packaging designs, but the designs were expensive and complicated to implement. However, the S-L program gave students the opportunity to deal with real clients, so 
their designs had to be realistic for use by micro industries. Moreover, the goal of the S-L program was to solve the problems of the clients. In contrast, the regular class only created designs that were mostly fictitious. A S-L program also provides valuable learning outside of theory and in terms of communication, such as self-control and empathy. The limitations that the students faced were not always negative but could be positive experiences as well. There were also different aspects of the S-L program when considering a client's boundaries. We saw that these boundaries helped to prepare students to meet real clients in their future careers. Besides gaining technical skills, students had to develop their soft skills. In the S-L program, students had to be well prepared before they met their clients, as compared to meeting with their tutors. We saw this as a good experience. Students learned how to deal with clients with different economic, cultural, and social backgrounds. They felt they had to understand their clients' needs. Students often felt that because of the budget, they could not create a good design. However, this challenged students to make creative designs with a limited budget. Students perceived obstacles in various ways, but through the difficulties we believe that they can improve the quality of their designs.

From the students' reflections, we saw that S-L enhances active learning, develops students' civic responsibility and citizenship, develops the students' character, and contributes packaging design to the community. S-L turns obstacles into challenges and problems into solutions. The S-L program made us reform our curriculum of the packaging design class. Our new objective became to provide knowledge about packaging design in both theory and application, from idea to final form, to provide an experience for students in packaging design, and to create real solutions for factual packaging design problems (DKV Guide Book, 2014). Even now, the S-L program could still enhance the learning of packaging design in the ways that students show their technical and soft skills.

This study has some limitations. First, data collected by examining selected students' reflections have potential inadequacy, as Visual Communication Design students prefer things that are visual (such as drawing) rather than verbal (such as writing). Some students could not express what they felt and thought about servicelearning well. Second, a specific field of study (packaging design) makes a specific approach for learning. Further study in another field of design is needed to look into different approaches.

\section{Acknowledgments}

We would like to acknowledge the Research and Community Outreach Centre (LPPM) at Petra Christian University for their assistance in facilitating the S-L activities in the Visual Communication Design Department. Our thanks, also, to all packaging design tutors and students, especially those who had been involved in service-learning in 2006-2018. Thank you also to all parties, districts, sub-districts, city governments, industries, and micro industries for the great cooperation. 


\section{References}

Bonwell, C. C., \& Eison, J. A. (1991). Active learning: Creating excitement in the classroom (ASH\#-ERIC Higher Education Report No. 1). Washington, DC: The George Washington University, School of Education and Human Development.

Brame, C. (2016). Active learning. Vanderbilt University Center for Teaching. Retrieved from https://cft.vanderbilt.edu/active-learning/

Bringle, R. G., \& Hatcher, J. A. (2010). International service learning. In R. G. Bringle, J. A. Hatcher, \& S. A Jones (Eds.), International service learning: Conceptual frameworks and research (pp. 3-28). Sterling, VA: Stylus Publishing.

Buchanan, R. (1995). "Myth and maturity: Toward a new order in the decade of design.” In V. Margolin \& R. Buchanan (Eds.), The idea of design: A design issues reader (pp. 75-85). Cambridge, MA: MIT Press.

Campbell, J. (1998). Common questions faculty ask about service learning. Adapted from J. A. Hatcher (Ed.), Service-learning tip sheets: A faculty resource guide. Indianapolis, IN: Indiana Campus Compact. Retrieved from https://provisionsblog.files.wordpress.com/2012/03/sl-common-questions.pdf

Campus Compact. 1999. Presidents' declaration on the civic responsibility of higher education. Retrieved from https://kdp0143vw6z2dlw631ififc5-wpengine.netdna-ssl.com/wp-content/uploads/large/2009/02/Presidents-Declaration.pdf

Chickering, A. W., \& Gamson, Z. F. (1987, March). Seven principles for good practice in undergraduate education. AAHE Bulletin, 3-7.

DKV Guide Book. (2014). Punakawan: The legend returns. Surabaya, Indonesia: Desain Komunikasi Visual UK Petra.

Dubinsky, J. (2006). The role of reflection in service learning. Business Communication Quarterly, 69(3), 306-311. doi:10.1177/108056990606900308

Eyler, J., Giles, D. E., Jr., \& Schmiede, A. (1996). A practitioner's guide to reflection in service-learning: Student voices and reflections. Nashville, TN: Vanderbilt University.

Gateway Technical College. (2013). Service learning reflection toolkit. Retrieved from https://www.gtc.edu/ sites/default/files/files/documents/Service_Learning_Reflection_Toolkit.pdf

Goldsmith, S. (1995). Journal reflection: A resource guide for community service leaders and educators engaged in service learning. Washington, DC: American Alliance for Rights and Responsibilities.

Gottlieb, K., \& Robinson, G. (Eds.). (2006). A practical guide for integrating civic responsibility into the curriculum (2nd ed.). Washington DC: Community College Press. Retrieved from https://files.eric.ed.gov/fulltext/ED509538.pdf

Jurusan Deskomvis [Visual Communication Design Department]. (2006). Buku Panduan Jurusan Deskomvis Fakultas Seni dan Desain. Surabaya, Indonesia: Universitas Kristen Petra.

Natadjaja, L., \& Cahyono, Y. B. (2009). The impact of service-learning in supporting family empowerment and welfare program. New Horizons in Education, 57(3), 91-104. 
National Commission on Service Learning. (2002). Learning in deed: The power of service-learning for American schools. Newton, MA: National Commission on Service-Learning. Retrieved from http://ed253jcu.pbworks.com/f/LearningDeedServiceLearning_American+Schools.PDF

Rao, B. D. (2003). Higher education in the $21^{\text {st }}$ century vision and action. New Delhi, India: Discovery Publishing House.

Spallino, J. (2017). How character education helps kids learn and develop. Retrieved from https://www.methodschools.org/blog/how-character-education-helps-kids-learn-and-develop

Sturgill, A., \& Motley, P. (2014). Methods of reflection about service learning: Guided vs. free, dialogic vs. expressive, and public vs. private. Teaching E Learning Inquiry, 2(1), 81-93.

Waterman, A. S. (Ed.). (1997). Service learning: Applications from the research. New York, NY: Routledge.

Wijayanti, A., Maer, B., \& Fabrianne, A. (2017). Interviews by L. Natadjaja \& E. Yuwono.

Winings, K. (2002). Building character through service learning. Chapel Hill, NC: Character Development Publishing.

\section{Authors}

LISTIA NATADJAJA (listia@petra.ac.id) is an Associate Professor of Visual Communication Design, Faculty of Art and Design at Petra Christian University, Surabaya-Indonesia. She received her doctoral degree (2015) in Media and Cultural Studies from Gadjah Mada University, Yogyakarta-Indonesia. She has studied a wide range of multidisciplinary fields such as architecture, management, and multimedia design. Her current research interests include design, especially packaging design, service-learning, and media and cultural studies.

ELISABETH CHRISTINE YUWONO (xine_y@petra.ac.id) earned her Master's in Literature and Cultural Studies from Faculty of Humanities, Airlangga University Surabaya-Indonesia, in 2012. Her presentation thesis is about Madurese Masculinities on Illustration of Madurese Herbal Medicine for Men's Packagings. She is an Assistant Professor of Visual Communication Design, Faculty of Art and Design at Petra Christian University Surabaya-Indonesia. She has an interest in packaging design, typography, and visual and cultural studies. 